\title{
The Cambridge sheep - its exploitation for increased efficiency of lamb production
}

\author{
J.B. OWEN and I. AP DEWI \\ University of Wales, Bangor, School of Agricultural \& Forest Sciences, \\ Deiniol Road, Bangor, Gwynedd, LL57 2UW, England
}

\begin{abstract}
The Cambridge breed has been developed since 1964, based on a foundation group of 54 ewes representing 11 breeds mated initially to seven Finnsheep rams. Data presented show that a high litter size (LS) has been established (mean 2.8 in 3 year old ewes) by a policy of selection coupled with minimising generation interval.

Observations on ovulation rate (OR) show a large range $(1-13)$ and are consistent with an hypothesis that $\mathrm{OR}$ is influenced by a major gene effect superimposed on a basal level of about 2.5 ova. The gene appears to increase ovulation by about two ova per copy and to have a frequency approaching 0.3 in the Bangor University flock.

Data on the relationship of LS at birth and of lambs weaned per ewe are presented which indicate that under ideal conditions the optima for OR and LS at birth cannot exceed 5 and 3.5 respectively for mature ewes.

The practical utilisation of the breed as a dam-line sire of crossbred ewes show that the Cambridge crossbreds are more precocious, more prolific, have slower growing lambs with carcasses of similar quality to the corresponding Border Leicester crosses. Overall superiority in efficiency of feed utilisation is about $20 \%$. Methods of genotyping sheep and utilising the major gene in practice are discussed.
\end{abstract}

Index words: Cambridge, Finnsheep, ovulation rate, litter size, major gene, precocity, feed efficiency

\section{Introduction}

The Cambridge $(\mathrm{C})$ breed was established in 1964 at Cambridge University by screening British breeds for ewes with high litter sizes (LS). The foundation flock of 54 ewes included a total of 11 breeds although the majority were Clun Forest (34 ewes), Llanwenog (6 ewes) and Lleyn (3 ewes). The seven founda- tion sires were Finnsheep (F). By initial backcrossing to the foundation ewes the genetic contribution of $\mathrm{F}$ was reduced to $20-25 \%$.

Selection in the initial stage was primarily based on LS at birth and the generation length was minimised by confining matings to sires of 7 months old and to dams mainly up to 2 years old.

From 1969 the foundation flock was part- 
ly disseminated to a small group of cooperating breeders (10-12 members). In 1983 the Cambridge Sheep Society was formally established and in September 1985 the first of the Society's annual sales was held at Malvern, England.

Since 1975 selection criteria have been widened to include, in addition to LS, an emphasis on milking ability and meat quality related to the needs of the European Market.

The paper describes the performance of pure $\mathrm{C}$ stock, evidence for the genetic basis of the prolificacy achieved and the transmission of prolificacy to maximise lamb production efficiency in crossbred ewes kept under commercial conditions.

These findings are discussed in relation to the strategy for future deployment of prolific sheep genotypes.

\section{Material and methods}

Performance of pure bred $C$ : The results are based on the performance achieved in the flock kept at the University of Wales, Bangor, using methods described previously (6). Ovulation rates (OR) were recorded from October 1983 using the endoscope technique (2).

Performance of crossbred ewes: A contemporary comparison of crossbred ewe types was carried out in the period $1980-1985$ as described by Owen \& Whitaker (7). These included comparisons of crossbred ewes sired from Welsh Mountain dams by $\mathrm{C}$ or Border Leicester rams. In these experiments the crossbred ewes were mated mainly to Suffolk (S) rams.

In addition, some preliminary investigation was carried out into the effect of the mating

Table 1. Lambs born per ewe lambing in the Bangor flock 1983-1987.

\begin{tabular}{ccc}
\hline Age of ewe & No of ewes & Lambs born per ewe \\
\hline 1 & 224 & 1.6 \\
2 & 93 & 2.4 \\
3 & 142 & 2.8 \\
$4+$ & 139 & 3.0 \\
\hline
\end{tabular}

ram (C vs. S) on ovum survival when mated to Welsh Mountain ewes. This study involved a total of 136 ewes for which OR and lambing performance was recorded.

\section{Results and discussion}

The basis of prolificacy in the Cambridge breed

Table 1 summarises the prolificacy of $\mathrm{C}$ ewes in the Bangor flock in the years 1983 - 1988. The values for ewes of 4 years old and over are biassed because of the substantial rate of selection for prolificacy in these ewes.

Since the autumn of 1983 , data have been recorded for OR although the data do not necessarily include information for each age group in each year. Table 2 gives a frequency distribution for OR according to age. These observations, with the unusually high range of values and the within age $\mathrm{CV}$ of over 0.5 , are suggestive of the presence of a gene with a major effect, segregating in this population. Similar observations have been reported for the Booroola Merino (8).

The values for the repeatability of OR with-

Table 2. Frequency distribution for ovulation rate (no of corpora lutea) according to ewe age.

\begin{tabular}{crrrr}
\hline \multicolumn{5}{c}{ E83-1987 } \\
\hline & \multicolumn{4}{c}{ Ewe age at lambing } \\
\cline { 2 - 5 } Ovulation rate & 1 & 2 & 3 & $4+$ \\
\hline 1 & 22 & 9 & 5 & 3 \\
2 & 48 & 36 & 23 & 24 \\
3 & 33 & 43 & 43 & 34 \\
4 & 14 & 25 & 24 & 42 \\
5 & 14 & 9 & 7 & 27 \\
6 & - & 2 & 10 & 11 \\
7 & 3 & 6 & 3 & - \\
8 & - & 1 & 2 & 6 \\
9 & - & - & 1 & 3 \\
10 & - & - & 1 & - \\
11 & - & - & - & 1 \\
12 & 134 & 131 & 120 & 153 \\
13 & 2.7 & 3.2 & 3.7 & 4.1 \\
No of ewes & & & & 2 \\
Mean O.R. & & - & 1 & - \\
\hline
\end{tabular}


in ewe between years are also much higher than would normally be expected (2). The data for OR in this flock can be classified into three classes (or clusters), each relatively uniform within themselves and differing substantially in mean value (Table 3). Assuming that the three classes correspond to the genotypes $\mathrm{CC}$, $\mathrm{Cc} \&$ cc ( $\mathrm{C}$ being the 'Cambridge prolificacy' gene and $c$ its allele) the results suggest that the gene is present in this flock at a frequency of approximately 0.3 .

Prolificacy in $\mathrm{C}$ can be explained on the basis of a basal OR of about 2.5 upon which is superimposed a further additive increment of approximately 2 ova per copy of a major gene.

Another interesting facet of the observations in the high level of ovum survival (OS) indicated by the data as shown in Figure 1 as compared to other breeds of high prolificacy (1). This high level of OS needs confirmation in controlled comparisons under similar conditions. The data as they stand do not indicate any obvious relationship between this enhanced level of OS and the presence of the major gene since it appears throughout the range of OR studied.

Limited preliminary data (Figure 2) do not support the hypothesis that OS is influenced by ram breed as noted by Meyer (5) in his observations on different breeds.

\section{Optimum prolificacy}

The study of this unusual sheep population with a range of observed OR values from $1-13$ has afforded an opportunity for the

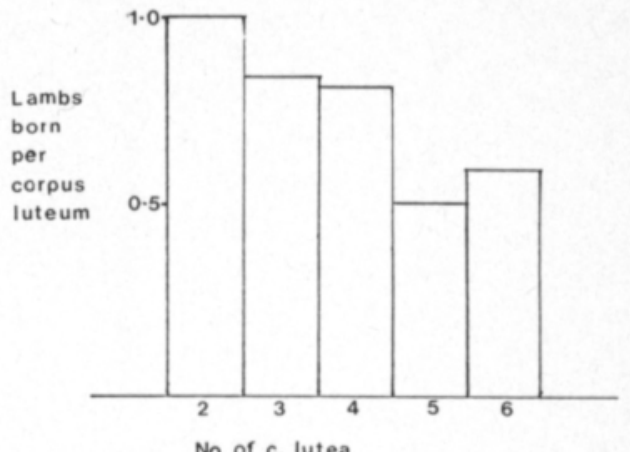

Fig. 1. Preliminary data on ovum survival in relation to ovulation rate.

first time to address in detail the important problem of where the range of optima for OR and LS in sheep are likely to lie. The involvement at Bangor with studies of Welsh Mountain Sheep and collaborative studies of Awassi sheep under semi-arid ranges (3) has clearly emphasised that the appropriate economic optima for conditions with severe constraints are an OR and LS of one.

In contrast, Figure 3 shows the range of values for the number of lambs reared (to 50 days) per ewe in relation to OR and to LS in $\mathrm{C}$ under good lowland husbandry conditions. These indicate that the economic optima for OR and LS are unlikely to exceed 5 and 3.5 respectively for mature ewes.

\section{Performance of Cambridge crossbred ewes}

Early comparisons of $\mathrm{C}$ as a dam-line sire of crossbred ewes indicated that $\mathrm{C}$ crossbred ewes gave birth to $14 \%$ more lambs and

Table 3. Ovulation rates for two and three year old ewes classified into three genotype classes observed in the period 1983-1987.

\begin{tabular}{lccccc}
\hline $\begin{array}{l}\text { Age of } \\
\text { ewe }\end{array}$ & $\begin{array}{c}\text { Classification } \\
\text { criterion }\end{array}$ & $\begin{array}{c}\text { Presumed } \\
\text { genotype }\end{array}$ & $\begin{array}{c}\text { No of } \\
\text { ewes }\end{array}$ & $\begin{array}{c}\text { Mean } \\
\text { ovulation } \\
\text { rate }\end{array}$ & $\begin{array}{c}\text { Coefficient } \\
\text { of } \\
\text { variation }\end{array}$ \\
\hline 3 & $1-3$ & cc & 71 & 2.5 & 0.25 \\
& $4-6$ & Cc & 41 & 4.7 & 0.18 \\
2 & $7-12$ & CC & 8 & 8.5 & 0.21 \\
& $1-3$ & cc & 88 & 2.4 & 0.28 \\
& $4-6$ & Cc & 36 & 4.4 & 0.14 \\
\hline
\end{tabular}




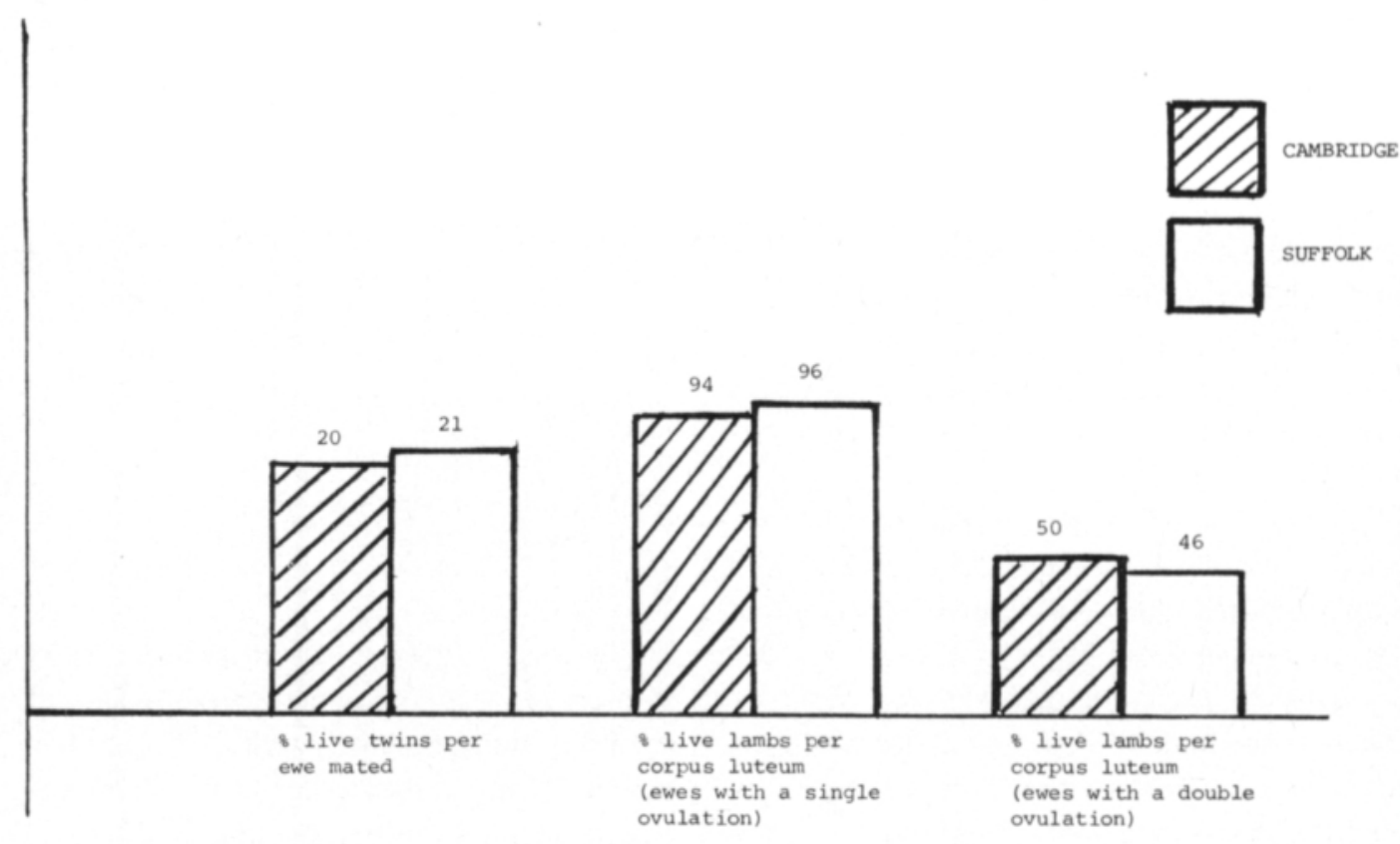

Fig. 2. Comparison of Cambridge and Suffolk in terms of the ovum survival of ewes to whom they were mated.

reared $6 \%$ more at weaning than Border Leicester sired crossbreds although the latter crossbreds gave lambs that were $4 \%$ heavier at 18 weeks old (4). The more recent comparison based on crossbred ewes born in the period 1980-83 have the results shown in Table 4.

These results indicate that $\mathrm{C}$ crossbreds are earlier in reproductive maturity and produce at least $20 \%$ more lambs per ewe lambing. The weight and quality of the final lamb (as judged by UK Meat and Livestock Commission grading) was similar for the $\mathrm{C}$ and Border Leicester crossbred. The $\mathrm{C}$ crossbred ewe was however $7 \%$ lighter in mating weight and reared lambs $22 \%$ lighter at 56 days of age. Overall, taking estimated feed intake into account, it was calculated that the C crossbred ewes were approximately $20 \%$ more efficient in terms of lamb production per unit of feed intake.

\section{Strategy for the future deployment of prolific sheep genotypes}

The foregoing observations suggest that in practice the optimum exploitation of geno- types like the $\mathrm{C}$, that may carry a gene with a major effect on $\mathrm{OR}$, is to produce commercial crossbred ewes heterozygous for this gene. Such a ewe would have the advantage of possessing prolificacy at a rate likely to be near the economic optimum under good husbandry conditions whilst at the same time exhibiting low (or normal) variability of LS (as measured in terms of $\mathrm{CV}$ in the region of 0.3 ).

The main problem arises in securing a supply of crossing rams proven homozygous for the $\mathrm{C}$ gene. This could be done by establishing flocks where the prolificacy gene is fixed at the locus in question or by developing a practical diagnostic technique for early genotyping of the male. The first alternative would obviously be helped by the availability of the diagnostic technique.

Table 5 summarises the observed OR for 8 month old daughters of $\mathrm{C}$ sires measured in 1985 and 1987. These results suggest that even against the background of a ewe flock with a $\mathrm{C}$ gene frequency of about 0.3 it should be possible to make some useful preliminary assessment of the genotype of a ram when his daughters are 8 months old and he himself is 


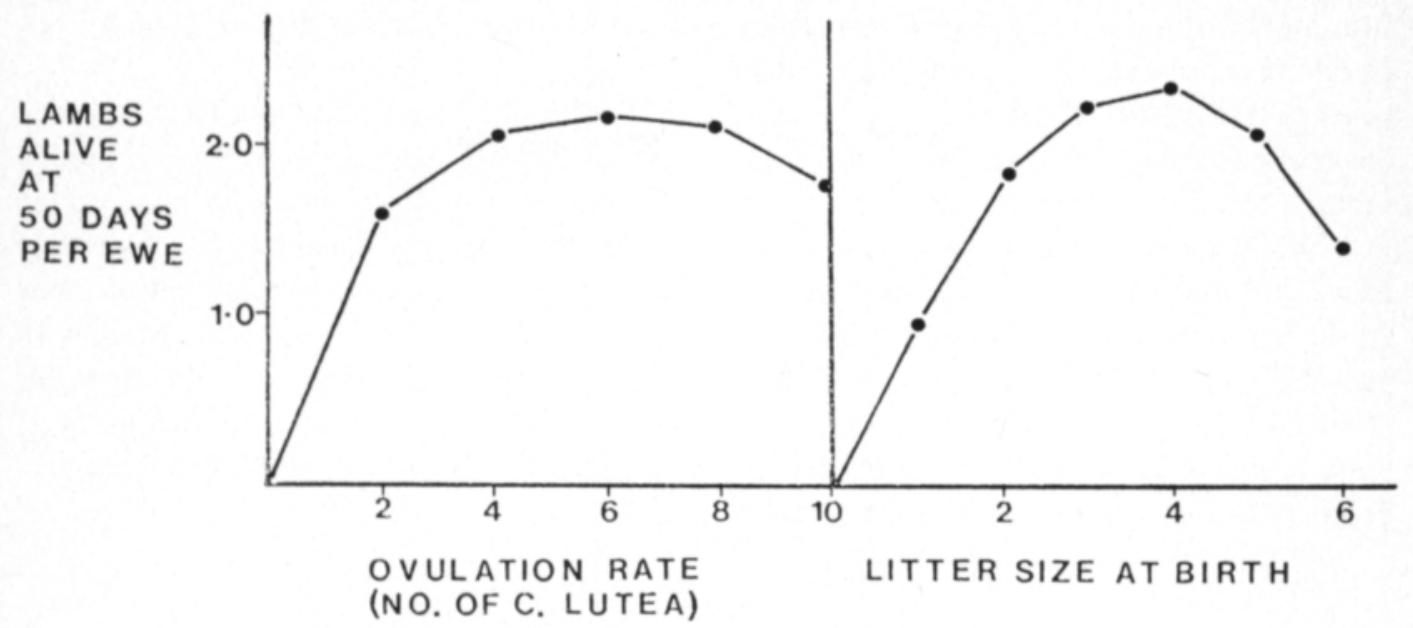

Fig. 3. Lambs surviving to 50 days in relation to ovulation rate and litter size at birth.

Table 4. Comparative lambing performance of crossbred ewes sired by Border Leicester and Cambridge rams (see OWEN \& WhitAKER, 1987).

\begin{tabular}{lrr}
\hline & \multicolumn{2}{c}{ Crossbred ewe sire breed } \\
\cline { 2 - 3 } Ewe weight at mating & Border Leicester & Cambridge \\
Ewes lambing at 1yr & 100 & 93 \\
Lambs born per ewe lambing at 1yr old & 100 & 128 \\
Lambs reared to 56d per ewe lambing at 1yr old & 100 & 138 \\
Lambs born per ewe lambing at 2 \& 3yrs old & 100 & 151 \\
Lambs reared to 56d per ewe lambing at 2 \& 3yr old & 100 & 113 \\
Mean age at slaughter (all lambs) & 100 & 115 \\
Mean weight at slaughter (all lambs) & 100 & 115 \\
Efficiency of lamb production (lamb production - & 100 & 97 \\
estimated feed intake) & & 100 \\
\hline
\end{tabular}

Table 5. Ovulation rate data for the progeny of rams measured as 8 month old females.

\begin{tabular}{lrcccccc}
\hline Sire & $\mathrm{n}$ & Mean & Range & Sire & $\mathrm{n}$ & Mean & Range \\
\hline 4023 & 3 & 1.3 & $1-2$ & 6002 & 4 & 2.8 & $2-4$ \\
4029 & 1 & 1.0 & $*$ & 6062 & 6 & 2.7 & $2-3$ \\
4062 & 8 & 2.9 & $1-5$ & 6078 & 12 & 2.4 & $1-4$ \\
4106 & 5 & 3.2 & $1-5$ & 6097 & 7 & 3.3 & $1-7$ \\
4114 & 7 & 2.3 & $2-3$ & 6107 & 6 & 2.2 & $1-3$ \\
4117 & 10 & 3.1 & $0-5$ & 6161 & 8 & 2.9 & $1-5$ \\
4129 & 5 & 3.0 & $1-5$ & 6166 & 8 & 2.1 & $1-4$ \\
4136 & 3 & 2.0 & $2-2$ & 6187 & 2 & 3.5 & $2-5$ \\
4165 & 6 & 2.5 & $1-5$ & 6191 & 7 & 4 & $2-4$ \\
4184 & 7 & 2.3 & $2-3$ & 6321 & 4 & 4.5 & $3-7$ \\
4194 & 5 & 2.6 & $1-4$ & 6351 & 6 & 3.2 & $1-5$ \\
4275 & 4 & 1.5 & $1-2$ & & & & \\
\hline
\end{tabular}


21 months. Because of the high repeatability of OR it is possible to discriminate usefully between females of differing genotypes on the basis of their own OR even at the age of 8 months.

A sub flock of $\mathrm{C}$ has already been established at Bangor based on rams progeny tested on the basis of their 8 month old female progeny mated to small groups of ewes of high $(7+)$ OR. If this method proves successful then such subflocks can be developed by breeders as one way of supplying a possible future demand for rams homozygous for the $\mathrm{C}$ gene.

A more direct possibility for detecting genotype at an early age is to apply the techniques of molecular biology. Work in progress at Bangor has the aim of enabling genotype with respect to the $\mathrm{C}$ gene to be determined from tissue (e.g. blood) taken from young lambs of either sex. Such a technique would allow the rapid exploitation of prolificacy genes in sheep to increase efficiency of lamb production.

\section{References}

1. Hanrahan, J.P. (1987). Genetic variation in ovulation rate in sheep. In New Techniques in Sheep Production edited by I.M.F. Maral \& J.B. Owen, PP 37-46, Butterworths, London.

2. Hanrahan, J.P. and Owen, J.B. (1985). Variation and repeatability of ovulation rate of Cambridge ewes. Anim. Prod. 40, 529 (ABS).

3. Kassem, R., 1987. Reproduction in the Awassi ewe under semi arid conditions. PhD thesis. Univ. of Wales.

4. Mann, T.S.L., Smith, C., King, J.W.B., Nicholson, D. \& SAlES, D.I. (1984). Comparison of crossbred ewes from five crossing sire breeds. Anim. Prod. 39, $241-249$.

5. Meyer, H.H. (1985). Breed differences in ovulation rate and uterine efficiency and their contribution to

fecundity. In: 'Genetics of Reproduction in Sheep' (Eds. R.B. LAND \& D.W. RoBinson), Butterworths, London: $185-191$.

6. Owen, J.B. Crees, S.R.E., Williams, J.C. \& Davies, D.A.R., 1986. Prolificacy and 50-day lamb weight of ewes in the Cambridge sheep breed. Anim. Prod. 42: $355-363$.

7. Owen, J.B. \& Whitaker, C.J. (1987). A comparison of cross-bred ewes raised from Welsh Mountain dams by three sire breeds: Cambridge, Border Leicester and Lleyn. J. Agric. Sci. 109, 159-164.

8. Piper, L.R., Bindon, B.M. \& Davies, G.H. (1985). The single gene inheritance of the high litter size of the Booroola Merino. In: Genetics of reproduction in sheep (Eds. R.B. LAND \& D.W. RoBinson), Butterworths, London: 115-126. 